\title{
COMMENT
}

\section{RELOCATION, ACCIDENTAL INEQUALITIES, AND THE EQUAL PROTECTION DOCTRINE}

In a meritorious endeavor to clear the slums and rehouse the poor, Congress passed the Housing Act of 1949.' The declaration of policy in the Act expresses the intention to strive for no less than a "decent home and suitable living environment for every American family," 2 while section 105(c) boldly guarantees "decent, safe, and sanitary" housing for displacees forced to vacate slum clearance projects. $^{3}$ Section 105 (c) further provides for the conditions of the contract between the local planning agency (LPA) and the Department of Housing and Urban Development (HUD) —originally the Housing and Home Finance Agency (HHFA) - to preclude the grant of federal funds until HUD has determined that the rehousing offered displacees has satisfied or will satisfy the statutory standards."

\footnotetext{
1 Ch. 338, 63 Stat. 413.

2 Housing Act of 1949, §2, 42 U.S.C. $\S 1441$ (1964), as amended, (Supp. III,
} 1968).

The Congress declares that the general welfare and security of the Nation and the health and living standards of its people require housing production and related community development sufficient to remedy the serious housing shortage, the elimination of substandard and other inadequate housing through the clearance of slums and blighted areas, and the realization as soon as feasible of the goal of a decent home and suitable living environment for every American family ... The Housing and Home Finance Agency and its constituent agencies ... shall exercise their powers, functions, and duties under this or any other law, consistently with the national housing policy declared by this Act . . . .

3 Housing Act of 1949, ch. 338, $\S 105$ (c), 63 Stat. 416, originally provided:

Contracts for financial aid shall be made only with a duly authorized local public agency and shall require that-

(c) There be a feasible method for the temporary relocation of families displaced from the project area, and that there are or are being provided, in the project area or in other areas not generally less desirable in regard to public utilities and public and commercial facilities and at rents or prices within the financial means of the families displaced from the project area, decent, safe, and sanitary dwellings equal in number to the number of and available to such displaced families and reasonably accessible to their places of employment ....

Section 105(c) was subsequently strengthened by the 1964 amendment, which extended coverage to individuals as well as families and required that each local planning agency institute a relocation assistance program to meet the needs of displacees. 42 U.S.C. $\$ 1455$ (c) (1) (Supp. III, 1968).

4 Prior to the creation of HUD, the HHFA Administrator had been charged with the non-delegable responsibility for making the statutory feasibility decision. 42 U.S.C. $\$ 1451$ (c) (1964). This decision-making responsibility is now the function of the Assistant Secretary for Renewal and Housing Assistance within the Department of Housing and Urban Development. 31 Fed. Reg. \$\$8964-65 (1966). See also $\$ 105$ (c) (2) of the Act, 42 U.S.C. $\$ 1455$ (c) (2) (Supp. III, 1968). 
By combining this Act with existing public housing titles, Congress hoped that public housing would fill the gap created by the extreme shortage of adequate private housing, and serve as the primary source of relocation for displacees. ${ }^{6}$ By the 1950's, however, public housing had suffered serious setbacks at the local levels where it was administered.

Too liberal in concept for conservatives and too conservative in practice for liberals, public housing reached its nadir in 1954, when Congress, reflecting public apathy, cut the annual authorization from 135,000 to a mere 35,000 units. $^{8}$ Slum clearance, rather than being curtailed, simply changed its emphasis. Staggered by the flow of the white middle class to the suburbs, urban leaders saw in renewal projects a method of rebuilding their eroded tax base. Rather than build low income public housing to relocate displacees, local administrators decided to emphasize the construction of shopping centers, office buildings, luxury apartments and expensive townhouses, to lure tax dollars back to the city. ${ }^{9}$ The concern, then, shifted to attracting the suburban rich rather than rehousing the urban poor. Local planning agencies and the federal government became less and less concerned with the misfortunes of displacees. ${ }^{10}$

Due to this neglect, slum dwellers no longer could hope to gain the promised "decent" housing and all the benefits that accrue from it; in fact, slum clearance soon put their very welfare in jeopardy. Studies show that upon notice of eviction from his home the typical displacee could expect to spend great lengths of time searching for shelter only to find rehousing that was more expensive, more crowded, and less adequate than the "slum" from which he had been displaced. ${ }^{11}$

This displacement has not been random in its effect; on the contrary, the process has worked selectively. Renewal critics point out

5 E.g., 42 U.S.C. $\$ 1410$ (1964).

- See generally HHFA, The Relationship Between Slum Claarance and URBAN REDEVELOPMENT AND LOW-RENT Housing (1950), as cited in Note, Judicial Review of Displacee Relocation in Urban Renerval, 77 YALE L.J. 966, 980 (1968) [hereinafter cited as Note, Displacee Relocation].

7 It should be noted that the statute and its legislative history emphasize that the planning and administration of these programs are a local responsibility. Housing Act of 1949, $\$ \$ 2,101,42$ U.S.C. $\$ \$ 1441,1451$ (1949) ; S. REP. No. 84, 81st Cong., 1st Sess. 27 (1949).

8 C. Abrams, The City Is the Frontrer 80 (1965) [hereinafter cited as Abrams]; R. Fisher, Twenty Years of Public Housing 102 (1959).

9 See Von Eckhardt, Black Neck in a White Noose, NEw Republic, Oct. 19, 1963, at 15; Von Eckhardt, Bulldozers and Bureaucrats, New Republic, Sept. 14, 1963, at 14; Tondro, Urban Renewal Relocation: Problens in Enforcennent of Conditions on Federal Grants to Local Agencies, 117 U. PA. L. REv. 183, 198 (1968) [hereinafter cited as Tondro].

10 For a discussion of the new emphasis and the consequent neglect of displacees on the part of both the LPAs and the federal government, see ABRAMS 132-54.

11 E.g., Hartman, The Housing of Relocated Families, 30 J. An. Inst. Planners 270-78 (1964) [hereinafter cited as Hartman]. Hartman bases his conclusions on extensive analysis of previous investigations of relocation as well as his own empirical research on relocation in the Boston West End renewal area. His conclusions are, furthermore, representative of other critics. See also Tondro 226. 
that approximately two-thirds of the people forced out of their homes each year are Negroes, Puerto Ricans, or members of some other minority group. ${ }^{12}$ The normal burden of finding decent living quarters is magnified for them by the intense and rampant discrimination in the housing market. ${ }^{13}$

For example, while it may take the white displacees weeks to relocate, it takes the nonwhite months. While the white displacee may utilize real estate agencies and newspapers, the nonwhite must often rely on informal information provided by family and friends. Furthermore, the prospective Negro homeowner experiences much more difficulty in securing adequate financing than his white counterpart. $^{14}$ In addition, when the search is over, nonwhites invariably end up with housing that is higher priced, more crowded, and substantially less habitable than that obtained by the white displacee. Finally, the nonwhite usually ends up in a highly segregated slum area that is the target of urban renewal projects yet to come. Thus, the cycle of injustice repeats itself and nonwhites are kicked around from one project site to the next. ${ }^{15}$

This process has left psychological scars not only on the nonwhite displacees, but on society as a whole. Renewal has come to mean the displacement of nonwhites by whites or by the symbols of white culture; and, therefore, many Negroes have come to regard renewal not as a cure for society's ills, but as a deliberate conspiracy by the white power structure to displace them because they are black. ${ }^{16}$

Because the traditional legislative and administrative institutions have not been responsive to the plight of nonwhite displacees, grievances concerning relocation have quite predictably, and appropriately, shifted to the courtroom. ${ }^{17}$ Norwalk CORE v. Norwalk Redevelopment Agency ${ }^{18}$ represents a recent, sensitive response by the federal courts to this problem. ${ }^{19}$ It will serve as the focal point of discussion here.

12 Hartman 273-74; Tondro 184.

${ }^{13}$ Cf. Jones v. Alfred H. Mayer Co., 392 U.S. 409, 449, 449 n.6 (1968) (Douglas, J., concurring).

14 See U.S. Advisory Commission on Intergovernmental Retations, Reiocation: Unequal Treatarent of People and Businesses Displaced by GovernMENT 34-35 (1965).

15 Hartman 273-74.

16 See Congressional Quarterly, Congress aNd the Nation 469 (1965). The assertion that "urban renewal is Negro removal" was made by author James Baldwin on a television program in May of 1963. This phrase has gained some measure of recognition as many urban renewal critics have used it of late. See Tondro 185.

Wolf Von Eckhardt adds: "Many a high cost and high rise apartment project has been developed with tax money solely to stop Negro encroachment into some alderman's district." Von Eckhardt, Bulldozers and Bureaucrats, New REpubLIC, Sept. 14,1963 , at 14,17 .

17 See Note, Displacee Relocation 969.

18395 F.2d 920 (2d Cir. 1968).

10 It has been well settled that state remedies are inadequate. E.g., Tondro 21921 ; see also Note, Displacee Relocation 969, n.15. 


\section{Norwalk CORE v. Norwalk Redevelopment Agency}

The plaintiffs in Norwalk CORE represent a collection of interest groups and individuals concerned with gross mistreatment of nonwhites displaced from a large urban renewal project. ${ }^{20}$ The defendants, equally diverse, include institutions and their directors ranging from the Norwalk Redevelopment Agency (NRA) to Dr. Robert C. Weaver, then Secretary of HUD. ${ }^{21}$ Allegations in the complaint asserted typical examples of the difficulties nonwhites encounter in the displacement process.

The plaintiffs claimed that the NRA had experienced certain problems in planning for the project. Realizing that the Norwalk housing market was extremely limited due to discrimination in the private sector and long waiting lists for public housing, it allegedly proceeded to submit distorted relocation statistics in order to have the renewal project approved by HUD. Once the project was approved and initiated, the NRA reportedly refused to modify its plans and continued to displace nonwhites into the overcrowded market. Furthermore, in lieu of constructing desperately needed low-income public housing on the site's last available piece of land, the NRA contracted for the construction of a six-acre, ninety-unit, moderate-rent apartment complex completely beyond the financial reach of nonwhite displacees. The complaint states that as a result of these maneuvers, nonwhites were forced into overcrowded, high-rent slums, and in some cases were literally driven out of the city. ${ }^{22}$

Plaintiffs based their complaints on the equal protection clause of the fourteenth amendment and the amended section $105(\mathrm{c})$ of the Housing Act of 1949.23 They were turned away from the United States District Court for the District of Connecticut on the grounds that they had not presented a proper class action under rule 23 of the Federal Rules of Civil Procedure, and that neither the associations nor the individuals had "standing to challenge the official conduct here in question." 24 The Court of Appeals for the Second Circuit

20 Plaintiffs consisted of the Norwalk Chapter of the Congress of Racial Equality, 2 non-profit tenants' associations comprised of low income Negroes and Puerto Ricans, and 8 individuals representing 4 classes of low income Negroes and Puerto Ricans: (a) those who were still living in the project area; (b) those who had been displaced into overcrowded rental units; (c) those who had been displaced into excessive rental values; and, (d) those who had been forced outside the City of Norwalk.

21 Defendants were the Norwalk Housing Authority, its Executive Director and members; the Norwalk Redevelopment Agency, its Administrator and members; the city of Norwalk, its mayor and city clerk; Town House Gardens, Inc.; David Katz \& Sons, Inc. ; Charles J. Horn, Assistant Regional Administrator for Renewal Assistance of the U.S. Department of Housing and Urban Development; and Dr. Robert C. Weaver, Secretary of the United States Department of Housing and Urban Development.

22395 F.2d at 924-25.

2342 U.S.C. \$1455(c) (Supp. III, 1968).

24 Norwalk CORE v. Norwalk Redevelopment Agency, 42 F.R.D. 617, 622 (D. Conn. 1967). The class action issue is not discussed in this Comment. 
reversed, holding that plaintiffs had standing to raise both the equal protection and the statutory issues and that they had indeed presented a proper class action. The case was remanded to the district court to be heard on the merits.

This decision is important for two reasons. The case marks the first time that a court has unequivocally removed the procedural roadblocks facing plaintiffs concerned with inadequate and improper methods of relocation, thus thrusting the judiciary into the position of reviewing the relocation plans and practices of governmental agencies. ${ }^{25}$ Second, although the court did not reach the substantive issue in the case, it did provide some insight into the scope of the rights granted to displacees and the effect those rights might have on future litigation.

\section{Equal Protection}

The plaintiffs in Norwalk CORE based two of their three claims on the equal protection clause of the fourteenth amendment: first, that the relocation program in Norwalk operated to deny the plaintiffs the equal protection of the laws; and second, that "the local defendants had intended to deprive low income Negro, and Puerto Rican families of the equal protection of the laws, and have intended to force such families out of the city." 26 The second claim thus follows the traditional approach to the doctrine: that equal protection is violated when the government, without adequate justification, either takes action with the purpose of disadvantaging a particular group, or, whatever its motives, takes different actions with respect to one group as compared with another, and thereby disadvantages one of the groups. ${ }^{27}$ The first claim, however, complains neither of an intent to harm one group more than others, nor of different actions taken for different groups; rather, the allegation simply refers to impartial governmental action that affects all site residents, but results in unequal consequences for nonwhite displacees.

During the rise of the civil rights movement in the early 1960's, a body of literature developed which served to clarify and justify this latter approach to the equal protection doctrine. ${ }^{28}$ It was felt that

25 Representative of earlier federal cases denying standing to displacees are Green Street Ass'n v. Daley, 373 F.2d 1 (7th Cir.), cert. denied, 387 U.S. 932 (1967); Johnson v. Oakland Redevelopment Agency, 317 F.2d 872 (9th Cir.), cert. denied, 375 U.S. 915 (1963); Harrison-Halsted Community Group, Inc. v. HHFA, 310 F.2d 99 (7th Cir. 1962), cert. denied, 373 U.S. 914 (1963). There is one trial court decision which granted standing for limited purposes, Powelton Civic Home Owners Ass'n v. HUD, 284 F. Supp. 809 (E.D. Pa. 1968).

26395 F.2d at 925 (emphasis added). The language quoted is the court's.

27 See generally Kaplan, Equal Justice in an Unequal World, $61 \mathrm{Nw}$. U. L. REv. 363 (1966); Tussman \& tenBroek, The Equal Protection of the Laves, 37 CaLIF. L. REv. 341 (1949).

28 E.g., N. Hentoff, The New EQUAIITY 97-112 (1964); Kaplan, supra note 27; Kellett, The Expansion of Equality, 37 S. CAL. L. REV. 400 (1964). 
when one group in society has been mistreated for an extended period of time, it accrues many social, economic and political liabilities that seriously hamper its members' chances to function within that society. Therefore, when the government administers programs with rigid equality, the disadvantaged group either is unable to benefit to the same extent or is subjected to a heavier burden than the rest of the community because of deficiencies in the requisite fundamental background. Those who are prepared advance, while the disadvantaged fall farther behind. The result would not be much different if the government had intended to harm or had taken different actions against the disadvantaged groups from the very beginning. ${ }^{29}$

Advocates of this view saw similarities to the special compensatory treatment given the physically disadvantaged in our society, and reasoned that the same approach should be applied to the sociologically disadvantaged..$^{30}$ Hence, to achieve an ideal balance, some groups should be treated unequally in order to equalize the final effect of governmental action.

In Hobson v. Hansen ${ }^{31}$ the District Court for the District of Columbia dramatically inaugurated this approach to the equal protection clause when reviewing the educational policies of the District's school board. ${ }^{32}$ The plaintiffs argued that the board's policies were diluting the quality of education provided for Negro school children. They alleged that a "neighborhood school" policy fostered de facto segregation, ${ }^{33}$ and that a "culturally biased" ability-grouping test administered in the earlier grades, using predominantly middle class vocabulary and language forms, invariably relegated Negroes to inferior curricular groupings. ${ }^{34}$ Although the court found enough positive factors in these policies to decide that the school board did not intend to harm Negroes, ${ }^{35}$ and although both the neighborhood school policy and the ability group-

29 See N. Hentoff, The New EQuarity 96-112 (1964).

$30 \mathrm{Id}$.

31269 F. Supp. 401 (D.D.C. 1967), aff'd, No. 21, 168 (D.C. Cir. Jan. 21, 1969) (en banc).

32 See Note, Hobson v. Hansen: Judicial Supervision of the Color-Blind School Board, 81 HARV. I. REv. 1511 (1968).

33 The District of Columbia school authorities followed a "neighborhood school policy" under which students were assigned to schools near their homes. In 11 of the 17 schools in the predominantly white northwestern section of the District, 85 to $100 \%$ of the students enrolled were white. In the remainder of the District, 139 of the 156 schools had a Negro enrollment of at least $85 \%$. The student enrollment throughout the entire District was $90.2 \%$ Negro. $269 \mathrm{~F}$. Supp. at 410-12.

34 These were nationally standardized examinations, which were developed as a means to distinguish students of differing aptitude in an effort to provide a viable basis for grouping that would avoid the inherent problems of a single curriculum too slow for gifted children and too demanding for others. According to expert testimony, these exams utilized a vocabulary and language forms alien to lower-class Negro children. The most important result averted to was that children who did poorly on the exams would be placed for the remainder of their educational career into a program designed to teach only basic concepts and geared to menial jobs. Id. at 511-15.

35269 F. Supp. at 418. 
ing test were applied to all students, it still held that Negroes were receiving unequal treatment because their particular social problems were not being taken into consideration. The court ordered that affirmative steps be taken, such as busing some Negro children to white schools, to reduce de facto segregation. ${ }^{36}$ Where de facto segregation could not be overcome "because of the density of social segregation or for other reasons," the court indicated that compensatory educational programs would have to be provided. ${ }^{37}$ In addition, the school board was ordered to abolish the ability-grouping system; ${ }^{38}$ however, the court may have left the door open for a modified version if the grouping is combined with compensatory programs and Negroes are provided an opportunity to work their way out of lower "ability" groups. The Hobson court thus adopted the equal protection concept mentioned above: it required that unequal attention be paid to disadvantaged Negro children in order to insure that the final effects of governmental action would be substantially equal.

The court in Norwalk CORE, quoting from Hobson, apparently adopted the expansive concept developed in that case. ${ }^{39}$ Unfortunately, however, the extent to which the court embraced this concept is not clear. In its discussion of whether there was standing to raise the equal protection issues, the court came to two conclusions. First, the allegations in the complaint of an intent to harm, if proved, would constitute a denial of the equal protection of the laws. ${ }^{40}$ The court also held that even if the harm done was not purposeful in the administration of the relocation plan, but was simply "accidental" to it, the planners are not excused from insuring that nonwhite rehousing reaches the same level as that available to white displacees. ${ }^{41}$

The decision could be said to declare that a failure on the part of IPAs to provide nonwhites with rehousing meeting the same standards as rehousing found by whites constitutes a violation of the equal protection clause. ${ }^{42}$ The Norwalk complaint-failure even to be rehoused at all within the city-easily falls within this expansive category and thus, if proved, would be a violation of the equal protection clause. Although it could be argued that the Norwalk decision simply held that deliberate discrimination without sufficient justification,

$36 I d$. at 509.

37 Id. at 515.

38 Id.

30 See $395 \mathrm{~F} .2 \mathrm{~d}$ at 931.

40395 F.2d at $930-31$.

41 See 395 F.2d at 931.

42 The theory that there can be a denial of equal protection by government action that is applied equally to all without an intent to harm one group in particular may be restricted by a requirement that the unequal effects of the relevant government action be reasonably foreseeable. The facts of both Norzvalk and Hobsen come within this narrower rule, and thus may leave undecided the question whether a denial of equal protection may result from government action with discriminatory consequences that were not reasonably foreseeable. 
if alleged and proved, constitutes a violation of equal protection, it would be hard to support such an argument against the emphatic language of the court.

Aside from its obvious substantive advantage to displacees, the former approach would also ease evidentiary burdens. Under the latter interpretation plaintiffs must prove a state of mind, ${ }^{43}$ whereas the former concept would merely require the showing of an unfavorable comparison between facilities available to whites and nonwhites.

Despite problems of interpretation, it seems that the expansive approach can be strongly supported by the language of Norwalk CORE. As the court concluded its discussion of the equal protection doctrine, it expressed its concern for the problem of classification by race. ${ }^{44}$ Classification according to race (which the court says may be required in order to remedy injustice ${ }^{45}$ ) becomes an issue only if the expansive approach is accepted: the LPA would be required to know exactly how many nonwhites would be displaced and the Authority would thereby be forced to take into account the full problem of displacement. The court concluded that racial classification for beneficial purposes is permissible. $^{46}$ Furthermore, there is the clear language that discriminatory results of a program administered with equality are not excusable merely because they are accidental. ${ }^{47}$ Thus, it would seem that the court would not have concerned itself with classification and "accidents" unless it had intended the expansive approach to be the standard in relocation problems. For purposes of further discussion, the expansive concept will be considered as the approach of the Norwalk court.

\section{Section 105(c) of the Housing Act}

Even a cursory reading of section $105(\mathrm{c}){ }^{48}$ reveals Congress's concern for families inadequately relocated. In light of this concern one would expect that such families would have little difficulty in obtaining judicial relief. Until the Norwalk opinion, however, such was not the case. In Green Street Association v. Daley, ${ }^{49}$ a relocation problem similar to that in Norwalk was involved. The court held, inter alia, that section 105 (c) conferred no private legal right upon displacees and consequently that displacees have no standing to sue. ${ }^{50}$

43 Of course, the state of mind may be inferred from the action if the latter is discriminatory on its face. For example, a plan denying rehousing assistance only to Negroes would presumably fall without further evidence of "intent."

44395 F.2d at 931-32.

$40 \mathrm{Id}$.

46 Id.

47 See text accompanying note 41 supra.

4842 U.S.C. $\$ 1455$ (c) (Supp. III, 1968).

49373 F.2d 1 (7th Cir.), cert. denied, 387 U.S. 932 (1967).

50 Id. at 8. 
Similarly, Johnson v. Oakland Redevelopment Agency ${ }^{51}$ held that section 105(c) provides only that the relocation requirements be included in loans or capital grants and that the requirements are merely contractual rights possessed by the federal government; therefore, reasoned the court, the requirements cannot be enforced by displacees. ${ }^{52}$

The Norwalk court dealt with these arguments by asserting that "the cases make it clear that the answer [to the question whether the displacees are 'aggrieved' within the meaning of section 10 of the Administrative Procedure Act, ${ }^{53}$ thus enabling them to obtain judicial review] turns on whether Congress' purpose in enacting [section 105 (c) ] was to protect their interests." 54 Looking to the legislative history, the court concluded that Congress did have a deep and abiding concern for the hardship of displacees and intended to protect their interests. ${ }^{55}$ Once this concern was established, the court denied the validity of defendants' "contract rights" theory, and stated that although Congress wanted the relocation provisions enforced by the federal government through contractual remedies, it is not inconsistent with that desire to allow another enforcement check by permitting dissatisfied displacees to air their grievances in court. ${ }^{56}$

The Green Street holding was also dismissed because of that decision's total reliance on Harrison-Halsted Community Group, Inc. v. Housing \& Home Finance Agency. ${ }^{57}$ To the Norwalk court, the Harrison-Halsted decision dealt primarily with commercial concerns and refused standing on the basis of a string of precedents holding that "injury through economic competition is generally not a sufficient basis for standing to sue." 58 However, the Norwalk court points out that even an economic interest can be the basis for standing when there is a statute that is intended to protect such an interest. Thus, the court concludes, if economic interest can support standing where the statute is one intended to protect those interests, the interests of displacees, which here are a focus of congressional concern, can also sup-

51317 F.2d 872 (9th Cir.), cert. denied, 375 U.S. 915 (1963). 205-14.

$62 I d$. at 874 . For a full discussion of these cases, see Tondro, supra note 9 , at

535 U.S.C.A. $\$ 702$ (1967).

54395 F.2d at 933.

55

The Bill sets up adequate safeguards against any undue hardship resulting from the undertaking of slum clearance under current conditions. It requires, first, that no slum-clearance project shall be undertaken by a local public agency unless there is a feasible means for the temporary relocation of the families to be displaced and unless adequate permanent housing is available, or is being made available to them.

395 F.2d at 933, quoting S. REP. No. 84, 81st Cong., 1st Sess. (1949) reprinted in U.S. Code Cong. \& ÁD. News 1550, 1554 (1949).

$56395 \mathrm{~F} .2 \mathrm{~d}$ at 934.

57310 F.2d 99 (7th Cir. 1962), cert. denied, 373 U.S. 914 (1963).

$58395 \mathrm{~F} .2 \mathrm{~d}$ at 935. 
port standing. ${ }^{59}$ Hence, displacees should possess legally enforceable rights under the statute. ${ }^{60}$

\section{The Need for a Constitutional Standard}

It appears that the high standards of section 105 (c) ${ }^{\text {a }}$ would provide more than adequate protection for slum dwellers. It seems odd, therefore, that a court would turn legal somersaults to develop the expansive approach - an approach which provides only relative protection to nonwhite displacees and virtually no substantial aid to white displacees. ${ }^{62}$ Closer examination of section 105 (c), however, reveals imperfections making the expansive equal protection approach a necessary legal sword for nonwhite displacees.

Remedial relief under section 105 (c) will most likely consist of enjoining renewal projects until the rights granted by the statute are accorded nonwhite displacees. ${ }^{63}$ Such injunctions may be extremely serious, however, because whatever immoralities are perpetrated on urban renewal's behalf, its existence has been deemed vital to the regrowth of the cities. ${ }^{64}$ If section 105 (c) were to be the basis of relief, renewal projects would be halted until "decent, safe, and sanitary" rehousing could be provided for slum dwellers. The problem is that housing meeting this statutory ideal is, of course, quite scarce. ${ }^{65}$ Hence, not only would it be impossible to provide the statutory ideal for nonwhites, but undoubtedly similar problems would be met in providing such housing for the less burdened white displacees. ${ }^{60}$

59 Id. at 935-36.

60 Id. The court also suggested that since relocation is in the public interest, therefore anybody affected by inadequate relocation might be able to sue on the basis of $\$ 105$ (c). See 395 F.2d at 934; see also Tondro, stpra note 9, at 212-14.

6142 U.S.C. $\$ 1455$ (c) (Supp. III, 1968).

62 The suggestion has been made that $\$ 105(\mathrm{c})$ only relates to judicial review of the activities of HUD. Thus, at least absent the acceptance of a third party beneficiary theory, statutory remedial relief might only be fashioned by compelling HUD to withhold funds from the LPA or to take other measures that would compel the LPA's to halt the projects. See Tondro, supra note 9, at 221-24. Such a remedy might be ineffective with the Norwalk project, however, because that project was in a late stage, and also because stopping the project is not desirable. Therefore, with no direct statutory relief against the local planning agency available, the constitutional equal protection argument-which is directed at the LPA and can require particular action-might be extremely important. However, as valid as this theory may be, the court at most implies it in its opinion, 395 F.2d at $926 \mathrm{n.7}, 929,935$, and furthermore does not make clear whether their grant of standing encompasses the third-party beneficiary theory.

63 See Tondro, sutpra note 9, at 223-24.

64 See, e.g., Abrams, supra note 8, at 180.

65 Were this scarcity not a fact, there would be no desperate outcry by social critics for a minimum of 6,000,000 new public housing units in the next 5 years. See Report of the National Advisory Conraission on CTVIL Disorders 475 (Bantam ed. 1968).

${ }^{66}$ While most authors agree that the burdens of relocation fall hardest on the nonwhite, implicit in their accounts of relocation is the fact that whites encounter their share of the difficulties also. See, e.g., Hartman, supra note 11, at 280. 
Obviously, if courts enjoin projects until the statutory ideal is met, and if this is applied on a wide enough scale, the effect will be to halt renewal until massive amounts of public housing are provided or the standards of section 105(c) are watered down by Congress. The former is improbable at present, and the latter is unlikely due to the brickbats that even the most conservative congressman would harvest by repudiating such an idealistic concept.

In view of the prospects of long range injunctions, LPAs (whose survival is vitally tied to renewal) would probably be motivated to distort relocation figures for the courts just as they do for HUD. ${ }^{67}$ Charles Abrams, a prominent writer in the field, seriously criticized a 1963 report published by the federal government based solely on the findings of individual LPAs. ${ }^{68}$ The report indicated that only 7.8 per cent of slum dwellers were relocated into substandard rehousing. Abrams argued that this remarkably rosy picture was a result of the subjective nature of determining what is "standard" rehousing. The values used by the LPA's in judging the concept of "standard" rehousing are not those of middle class America, or even those of the slum dwellers. Instead, they are the values created by the IPA's themselves, who have too great an interest in labeling all rehousing as "standard" so they can proceed with the task at hand (renewal rather than relocation) and so they can avoid delay or criticism from other concerned institutions or the public. ${ }^{69}$ Thus, the ideal notion of rehousing fostered by the statute becomes twisted into a simplistic notion of having a roof over one's head. ${ }^{70}$

The Norwalk court leaves room for further dissipation of the statutory standard. In the conclusion of its discussion of section 105 (c), it makes the following observation:

In determining whether there has been compliance with section 105 (c) of the Act, the courts will evaluate agency efforts and success at relocation with a realistic awareness of the problems facing urban renewal programs. Objections by individual displacees based on too literal an interpretation of the act's standards could unnecessarily interfere with programs of benefit to the entire community. ${ }^{71}$

67 E.g., ABRAMrs, stlpra note 8, at 141-45; see also Tondro, supra note 9, at 194-95, 199-200, 215-16.

68 See Abrasrs, supra note 8, at 138-39.

60 Id. at $140-41$.

70 One revealing insight into this problem is depicted by Terry Tondro when he cites an admission of "visual inspections through automobile windshields" by an embarrassed LPA whose inaccurate figures were discovered by the Government Accounting Office. Tondro, supra note 9, at 194.

71395 F.2d at $936-37$. 
A court that is hesitant to intervene in renewal policy decisions and faced with the task of judging rehousing facilities for several hundred displacees might easily seize upon this dictum and LPA statistics in order to approve the rehousing in question. In this way, it could avoid completely upsetting renewal machinery, and thereby antagonizing powerful interest groups.

Upon realization of the weakness inherent in enforcement of section 105 (c), it becomes apparent that the Norwalk court had suffcient reason to develop the expansive equal protection doctrine. This concept does not deal in terms of an unattainable goal, but rather provides a lower and more realistic standard: LPA's must comply with statutory requirements in relocating nonwhite displacees to the same extent they do in white relocation. Therefore, the nonwhite rehousing would not be matched against an unrealistic statutory requirement, but rather against provisions made for white displacees whose rehousing, although superior to that of nonwhites, may fall below the statutory requirements. In addition, once the standard of relocation for area whites has been established, it will be more concrete than the abstract concept of "decent, safe, and sanitary" housing.

To achieve such equal relocation, the 1964 amendment to section 105 (c) ${ }^{72}$ and the implicit recommendations of the Norwalk court would require the LPAs to establish special aids and programs designed to relocate nonwhites in adequate rehousing facilities. ${ }^{73}$ This could conceivably begin with having LPA representatives contact potential displacees before nonwhites have been frightened away by the prospect of being homeless, ${ }^{74}$ and supplying them with information concerning both realtors and available housing within the area, as well as being responsible for busing displacees to the new housing market area. Moreover, the LPA could establish a site office in the project area to afford displacees easy access to services offered and demonstrate the LPA's concern for their condition. ${ }^{75}$ Several renewal critics have regarded this type of organization and concern on the part of LPA's as the easiest and most fundamental approach toward alleviating injustices in relocation. ${ }^{76}$ In addition, the LPA could serve as a reference service by channeling the various types of federal aid, for example the provisions of the recent housing act, Housing and Urban Development

72 See note 3 supra.

73395 F.2d at 931-32, 935-36. As suggested above, it may be that the equal protection claim is necessary to directly force the LPA to do anything. See note 62 supra.

74 Some studies have shown that in certain projects as many as $25 \%$ or even $50 \%$ of the site residents never get the benefit of any relocation services because they are frightened away before any public agency can contact them. See, e.g., Tondro, supra note 9 , at $193-94$.

75 P. Nirbanck, Reiocation in Urban Planning: From Obstacle to OpporTUNIrY 78, 88 (1968). For a comprehensive review of possible LPA programs to aid displacees, see $i d$. at $75-107$.

76 See Hartman, supra note 11, at 329-30, 342. 
Act, ${ }^{77}$ to displacees. These programs will be of little help unless some local planning body is responsible for describing them to those needing relief and for referring those same people to the appropriate agencies.

Furthermore, fresh assistance could come from the recent open housing act in Congress, the Civil Rights Act of $1968,{ }^{78}$ and the recent decision of the Supreme Court, Jones v. Alfred H. Mayer Co., ${ }^{79}$ to provide some remedies against discrimination in the private housing market. ${ }^{80}$ LPAs not only could inform nonwhite displacees (and especially their interest groups) of their rights under these recent developments, but also could make use of the provisions of the Civil Rights Act of 1968. This law gives HUD the responsibility of investigating discrimination in the housing market with an eye towards conciliation, ${ }^{81}$ and the Attorney General the right to bring civil suits where there is a pattern of discrimination or any denial of the specified rights if the denial raises an issue of public importance. ${ }^{82}$ Hence, when the LPA encounters discrimination in its local community, HUD could attempt to arbitrate the matter. Should HUD's attempts fail, both the LPA and

77 Housing and Urban Development Act of 1968, Pub. L. 90-448 (August 1, 1968). Generally, this Act was intended to provide 1.7 million units of new and rehabilitated housing for low income families within the next 3 years. In addition, it will provide low income families with rent supplements and loans for prospective homeowners among them. This Act will be truly effective only if Congress sees fits to appropriate funds in order that this goal of public housing may be achieved.

78 Civil Rights Act of 1968, Pub. L. 90-284, 82 Stat. 73 (codified in scattered sections of 18,42 U.S.C.). Generally, the housing provisions of this Act prohibit discrimination on the basis of race, religion, or national origin in selling or renting housing, as well as in the services for selling and renting housing such as advertising, real estate and financial services. It will go into effect in 3 stages over a 3 year period, and by the end of that period over 80 per cent of the housing market will be covered by it. Exempted from the provisions of the Act are private individuals owning not more than 3 houses who sold their houses without a real estate broker and without advertising; also exempted are dwellings of up to 4 separate living units in which the owner maintains a residence.

79392 U.S. 409 (1968). The Court here held that $\$ 1$ of the Civil Rights Act of 1866, now 42 U.S.C. $\$ 1982$ (1964), barred any racial discrimination, private or public, in the sale or rental of housing. In contrast to the Civil Rights Act of 1968, it deals only with racial discrimination and not discrimination based on religion or national origin. It does not deal with advertising and does not provide special federal assistance to aggrieved parties. Furthermore, it does not specifically cover real estate or financial services. On the other hand, the 1866 Act contains no exemptions and is enforceable by private parties acting on their own initiative.

80 It has been suggested that even granting effective remedies against discrimination, many Negroes may be unwilling to be "pioneers" in white neighborhoods. See S. GreEr, URBan Renewal and AMerican Cities 58-9 (1965). This basic reluctance, however, would not seem to present an overwhelming obstacle. First, Greer himself presents evidence that a concerned promotion on the part of a sensitive LPA can overcome this reluctance. Id. at 57-8. Second, this fear would decrease if a reasonable number of displacees from the same project area were rehoused together in a neighborhood not completely foreign from their former residences. Third, the civil rights movement's support of open housing would seem to indicate that many nonwhites will accept housing in previously all-white neighborhoods.

81 Civil Rights Act of 1968, $\$ 808$ (a), 42 U.S.C.A. $\$ 3608$ (a) (Supp. 1968).

82 Civil Rights Act of 1968, §813(a), 42 U.S.C.A. \$3613(a) (Supp. 1968). 
HUD could inform the Attorney General, who could bring civil suits against the obstructionists. ${ }^{83}$

If the "expansive" goal proves to be a realistic one, the federal courts need not be fearful of destroying the renewal system through project injunctions. Although the requirement that nonwhites achieve equal standards in rehousing with whites will inevitably cause slowdowns, in time the problem should be eased. Once LPAs have established formal procedures to rehouse nonwhites, and the effect of open housing laws has created an impact on the housing market, LPAs should be able to relocate in a juster fashion.

Courts might also find that the slowdowns have unexpected remedial effects. Influential local interests that might otherwise have been unaware of (or, more likely, unconcerned with) the difficulties of nonwhite displacees may become keenly interested in their adequate relocation. In the Norwalk CORE situation, if the project is enjoined, other business interests waiting to continue construction on the project might see fit to use their influence to persuade Norwalk officials to forego their plans for moderate income apartments, and encourage them instead to construct public housing. ${ }^{84}$ Thus, the displacees would be rehoused and the area would be renewed. Furthermore, indirect assistance from the white power structure would become a continual process. Although whites represent only a minority of the displacees, ${ }^{85}$ their families, friends, associations, and businesses in some instances form powerful interest groups that can exert pressure on town councils and LPAs. By lobbying for better facilities and more public housing programs, they may prevent a reduction in relocation services. Thus, as whites protect and improve their standards, nonwhite displacees will also benefit since the adequacy of their facilities will be measured by the facilities available to the whites.

\section{CONCLUSION}

The Norwalk court fundamentally asserts that every displacee must be provided with relocation facilities. This requirement alone will cause government planning institutions to shift from a merely collateral concern with displacement to a full-fledged involvement in the relocation process. The real problem, however, centers on what standards these facilities are to meet. An examination of the realism adhered to by the Norwalk court indicates that in the immediate

83 Such action would be highly effective, but may not be within the activity which a court would order in fashioning relief. The Norwalk court noted that the plaintiffs were not demanding that the defendants end discrimination in the housing market or find integrated housing for the displacees. See 395 F.2d at 930.

84 Such a result would be particularly advantageous since the Norwalk court strongly implied the inappropriateness of judicial action concerning the six-acre plot. See 395 F.2d at 930.

85 See, e.g., S. Greer, Urban Renewal and American Cities 151 (1965). 
future the goal will be to match nonwhite with white rehousing. Enforcement of open housing laws, and implementation of special service programs by the LPAs could provide the primary stimulus for the equalization process. Furthermore, those groups affected by project slowdowns would have an incentive to use their influence to assure adequate relocation.

In the last analysis, then, it seems that the equal protection doctrine rather than section 105 (c) will preserve morality within the urban renewal process. Should the time come, however, when the nation sees fit to meet its domestic needs, the ideals of the Housing Act of 1949 and the standards of 105 (c) will not just be "realistically" applied, but will serve boldly as a Declaration of Rights for all renewal displacees. 